\title{
Improving the effectiveness of prevention in the context of the limits of the criminal law
}

\author{
Olesya Viktorovna Zaitseva ${ }^{1 *}$, Irina Vladimirovna Polikarpova ${ }^{1}$, Kazbek Muhamedovich \\ Khutov $^{1}$, and Dmitriy Viktorovich Zaitsev ${ }^{2}$ \\ ${ }^{1}$ Saratov State Law Academy, Department of Criminal and Penal Enforcement Law, Saratov, Russia \\ ${ }^{2}$ Saratov State Technical University named after Yuriy Gagarin, Department of Philosophy, \\ Sociology, Psychology, Saratov, Russia
}

\begin{abstract}
The rapid development of information and telecommunications technologies, the transformation of public relations caused by permanent socio-economic transformations which are happening in Russia and the world, result in numerous changes in criminal legislation and, as a result, problems associated with the establishment of spatial and temporal boundaries of criminal behavior. The purpose of the study is to develop practical recommendations aimed at improving the effectiveness of the preventive impact of criminal law by identifying the factors that determine the mentioned characteristics of a socially dangerous act. To solve these problems, the authors used the criminological tools of the study (the Bayesian method of time series forecasting, methods of questionnaires, and psychological analysis of criminal cases). In the article, for the first time, the problem of improving the effectiveness of criminal law prevention is considered in the context of the mechanism of individual criminal behavior. This allowed establishing that the spatial and temporal characteristics of a socially dangerous act do not depend on the structure of the crime, as it is considered in criminal science, but on the form of the offender's guilt. The criminological understanding of the crime allowed the authors to formulate proposals for improving the current criminal legislation and the practice of its application. The authors believe that in the case of intentional acts, when determining the optional features of the objective aspect of the crime, it is necessary to consider the place of full implementation of all the planned actions by the person, regardless of the place of occurrence of socially dangerous consequences. In the case of careless criminal encroachments, the territorial parameters of the occurrence of the criminal result should play a defining role. This article also describes the author's position on the place of commission of continuing and remote offenses.
\end{abstract}

Keywords: criminology, mechanism of criminal behavior, crime scene, crime prevention

\footnotetext{
*Corresponding author: zaitseva.o@bk.ru
} 


\section{Introduction}

The effectiveness of criminal law prevention depends on the correct application of the criminal law, including the precise establishment of space-time boundaries of a socially dangerous act. The analysis of the anti-criminal legislation of Russia has revealed that there is still no definition of the "place of commission of a crime", and there are gaps in the legal regulation of the place of continuing, remote and multi-subject crimes. This negatively affects the preventive potential of the criminal law, the activities of law enforcement officers, leads to red tape, and mistakes in qualification.

In foreign jurisprudence, certain aspects of the spatial boundaries of a crime are studied within the framework of the concept of environmentalist prevention in the context of territorial risk modeling [1-3] and rational choice theory [4-6]. In Russia, as a rule, they are considered, in the context of the principles of the criminal law in the circle of persons [7-9].

This article uses an unconventional, criminological view of the problem of establishing the limits of the criminal law in space, with regard to the mechanism of criminal behavior, which is based on the hypothesis that the spatial parameters of the crime are determined on the basis of a dynamic space-time model of the crime that exists in the mind of the delinquent.

The purpose of the study is to identify the factors that determine the spatial characteristics of a socially dangerous act. The conducted research allows resolving the following problems: to analyze the mechanism of criminal behavior; to identify the influence on the choice of the place of commission of a crime of the mental attitude of a person to the committed act and the criminal situation; to explore approaches to understanding the place of certain types of offenses; to formulate proposals for improving legislation.

\section{Methods}

The originality of the obtained scientific results is largely determined by the use of criminological methods (modeling, questionnaires, and psychological analysis of criminal cases). In order to calculate the probability of the occurrence of socially dangerous consequences of careless and intentional offenses, the Bayesian method of time series forecasting was used [10-12]. The Bayesian multidimensional model of common components is created with the use of the Monte Carlo Markov Chain algorithm (MCMC) in WinBUGS V.1.4.3 [13].

The empirical basis of the study was the results of a survey of law enforcement officers of the Saratov, Tambov, and Penza regions $(\mathrm{N}=100)$ on the limits of the criminal law, identifying correlations of crime indicators on the specifics of law enforcement activities. The survey was conducted with the use of the questionnaire method.

\section{$3 \quad$ Results}

The use of criminological research tools allowed establishing that the spatial characteristics of a socially dangerous act depend not only on the structure of the crime, as is commonly believed in the domestic criminal law science, but also on the form of the offender's guilt. Therefore, in the case of intentional offenses, the mentioned parameters of the crime should be determined by the place of the socially dangerous act, since it is the fact of committing an intentional illegal act that concentrates both objective and subjective danger, being the representation of the criminal will of the person.

In the case of careless encroachments, a socially dangerous act in itself, as a rule, does not generate the consequences that are the main criterion for establishing criminal liability, 
it does not contain a "genetic" pattern of causing harm [14]. Real negative changes in the surrounding reality are associated with the socially dangerous consequences, which should determine the territorial boundaries of careless criminal behavior. This definition of the crime scene is justified from the point of view of the prevention of offenses.

\section{Discussion}

The issue of the spatial limits of the criminal law is resolved in the Russian criminal law at the level of the principles of its personal scope of application (Articles 11, 12 of the Criminal Code of the Russian Federation). However, for the daily practical activities of law enforcement officers, including in the field of crime prevention, these principles can give little. It is more important to establish the correct location of the crime, and this issue has not been resolved at the legislative level yet. Most scientists, by analogy with Article 9 of the Criminal Code of the Russian Federation, consider the place of commission of a crime to be the place of commission of a socially dangerous act, regardless of the place of occurrence of criminal consequences [15]. However, this position does not consider the design features of individual elements of crimes.

Some authors propose to differentiate the definition of the crime scene with regard to the design of the crime (formal, material or truncated). This approach is also used in criminal procedure law $[16,17]$.

Criminological understanding of the operation of the criminal law in space proceeds from the difference between the legal and the actual moment of the end of the crime [18], giving priority to the latter. The fact that a person commits a crime is associated with the identity of the perpetrator, his/her moral and psychological characteristics, motivation, the process of forming the intention, and determination to implement the plan. In this regard, the crime is of interest to criminology from the position of the mechanism of its execution.

The mechanism of criminal behavior is referred to as the relationship of sociopsychological phenomena that consists of a set of external circumstances of objective reality (criminogenic situation) and mental processes and states that determine the decision to commit a crime, directing and controlling its implementation [19]. It includes a number of structural elements: motivation of the crime; planning of actions; implementation of the plan. Within the framework of the problem being considered, the last part is crucial. At the same time, the semantic line of the person's behavior is formed by the chain "goal - achieved result". Thus, in the mind of the subject, there is a dynamic space-time model of the crime. We believe that it shall determine the boundaries of the considered feature of the objective aspect of the crime, while the decisive factor is the awareness of the guilty person of the completion of a socially dangerous act.

For acts committed remotely particularly relevant is the problem of establishing the place of the offense (for example, theft of property using the Internet). The data obtained during the survey of law enforcement officers revealed that some law enforcement officers consider the location of the attacker to be the place of commission of these crimes, regardless of the place of transfer of funds to the victims and the place of crediting them to the account of the guilty person; others - the place where the criminal actually took possession of the funds, having received them from a credit institution; others - the location of the victim's bank account; fourth - the place of permanent residence of the latter (Figure 1). 

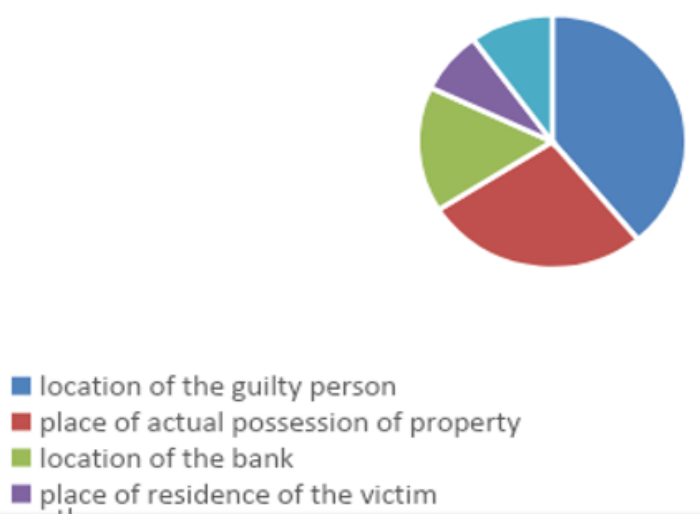

Fig. 1. The place of theft of non-cash funds.

As can be seen, in the practical activities of law enforcement officers, a unified approach to establishing the place of commission of a crime using remote methods of encroachment has not been developed. There is no certainty of views in the legal literature. For example, the German criminologist K. Cornils suggests considering in such cases the place of actions of the guilty [20]. V.G. Stepanov-Egiyants notes that if the person who committed a socially dangerous act is unknown, but the victim is known, a criminal case should be initiated on the territory of the state in which the victim operates [21]. D. Menthe believes that the place of Internet crime is not a specific territory, but cyberspace, which is not subject to national sovereignty [22]. A.I. Khaliullin believes that in such a situation it is necessary to consider the principle of citizenship, with regard to the physical location of the perpetrators and victims [23].

It is believed, the solution to this problem is possible based on the criminological understanding of the boundaries of criminal behavior $[24,25]$. The place of such crimes, regardless of the structure of the composition, should be recognized as the territory where the offender is located, since here all three links of the mechanism of criminal behavior (motivation, determination to commit a crime, and the implementation of the plan) come together. The guilty person in this case fully performs all the necessary actions to implement the planned theft, at this point, he/she already mentally reaches the intended goal in his/her mind.

Thus, the actual and legal moment of the end of the crime does not coincide. From a legal point of view, it is finished from the moment of withdrawal of money from the bank account of their owner, as a result of which the owner was harmed. In fact, it is committed at the time of the fraud, since the withdrawal of funds (causing damage) occurs automatically through the banking program, without the participation of the guilty person.

All of the above applies more to intentional criminal activity. But their mechanism differs significantly, the latter is "folded" in nature [26]. As for careless socially dangerous act, the boundary when potentially dangerous behavior becomes really dangerous is the moment of occurrence of harmful consequences, since at this time the offender is transformed into a criminal.

This is confirmed by the results of our study, according to which the probability of consequences $(\mathrm{P})$, calculated using Bayesian time-series forecasting methods, for negligent offenses was $1.5 \%(\mathrm{P}=0.015)$, while for intentional crimes - over $90 \%(\mathrm{P}=0.92)$. Therefore, in the case of careless criminal encroachments, when determining the spatial limits of the criminal law, one should be guided by the place of occurrence of socially dangerous consequences. 


\section{Conclusion}

With regard to the above, it is proposed to supplement the Criminal Code of the Russian Federation with Article 9.1 "Place of commission of a crime":

1. The place of commission of a deliberate crime is the place where the guilty person was actually present at the time of committing a socially dangerous act.

2. The place of commission of a crime committed by negligence shall be recognized as the place of occurrence of socially dangerous consequences.

The formulated conclusions and proposals contribute to improving the effectiveness of Russian criminal legislation, simplifying law enforcement practices, which will have a positive impact on its preventive potential.

The study was funded by RFBR, project number 20-011-00194.

\section{References}

1. R. Haining, J. Law, D. Griffith, Comp. Stat. and Data Anal. 53, 2923-2937 (2009). https://doi.org/10.1016/j.csda.2008.08.014

2. D. Hall, L. Liu, Annals of GIS 15(1), 61-71 (2009). https://doi.org/10.1080/19475680903271158

3. H. Liu and X. Zhu, Int. J. Geo-Inf. 6(1), 16 (2017). https://doi.org/10.3390/ijgi6010016.

4. E.R. Groff, J. Contemp. Crim. Justice 31(1), 90-160 (2015). https://doi.org/10.1177/1043986214552619

5. J. Law, M. Quick, P.W. Chan, Geo. Anal. 47(1), 1-19 (2015). https://doi.org/10.1111/gean.12047

6. C.P. Haberman, Crim. and Pub. Pol. 16(2), 633-660 (2017) https://doi.org/10.1111/1745-9133.12303

7. A.I. Boitsov, Ugolovnyi zakon: deistvie vo vremeni i prostranstve [Criminal law: application in time and space] (Publishing House of the Institute of Advanced Training of the Prosecutor's and Investigative Officers of the Prosecutor's Office of the RF, Saint Petersburg, 1993)

8. K.L. Akoev, Mesto soversheniya prestupleniya i ego ugolovno-pravovoe znachenie [The place of the crime and its criminal-legal significance], in A.V. Naumova (ed.) (Serviceshkola, Stavropol, 2000)

9. M.G. Reshnyak, Sovremennye problemy deistviya ugolovnogo zakona v prostranstve [Modern problems of the application of the criminal law in space] (Yurlitinform, Moscow, 2013)

10. M. Marsman, European J. Dev. Psy. 14(5), 545-555 (2017). https://doi.org/10.1080/17405629.2016.1259614

11. S. Depaoli, Psy. Meth. 2(22), 217-239 (2017). https://doi.org/10.1037/met0000100

12. C.R. Blakely, Int. J. Crim. Justice Sc. 14(2) (2019)

13. D.J. Lunn, A. Thomas, N. Bestu, D. Spiegelhalter, Stat. and Comp. 10(4), 325-337 (2000). https://doi.org/10.1023/A:1008929526011

14. A.P. Kozlov, Ponyatie prestupleniya [The concept of a crime] (Yurid. Centre Press, Saint Petersburg, 2004)

15. G.A. Esakov, Nastolnaya kniga sudi po ugolovnym delam [A desk book by a criminal judge], in A.I. Rarog (ed.) (TK Velbi, Prospekt Publishing House, Moscow, 2007)

16. L.L. Zaitseva, Law and Democracy, 26, 266-281 (2015)

17. Yu.A. Tyimoshenko, Legality, 7, 37-38 (2015) 
18. S.P. Bondarev, Humanities, Soc.-Ec. and Soc. Sc. 9, 204 (2014)

19. V.N. Kudryavtsev, Genezis prestupleniya. Opyt kriminologicheskogo modelirovaniya [The genesis of the crime. The experience of criminological modeling] (Norma, Moscow, 2018)

20. K. Cornils, Nord. Tidsskr. Forktiminalvid. København 3(86), 19 (1999).

21. V.G. Stepanov-Egiyants, Army and Soc. 5(42), 19 (2014)

22. D.C. Menthe, Michigan Telecom. and Tech. Law Rev. 4(1), 69-103 (1998)

23. A.I. Khaliullin, Actual Prob. Ec. and Law 1, 292 (2012)

24. J.E. Eck, D. Weisburd, Crime and Prevent. Stud. 4(1), 1-33 (1995). Accessed on: April 13, 2021. [Online]. Available: https://ssrn.com/abstract=2629856

25. L. Anselin, J. Cohen, D. Cook, W. Gorr, G. Tita, Crim. Just. 4(2), 213-262 (2000)

26. P.S. Dagel, Neostorozhnost. Ugolovno-pravovye i kriminologicheskie problemy [Carelessness. Criminal-legal and criminological problems] (Yurid. Lit., Moscow, 1977) 